\title{
МОЖЛИВОСТІ ІНТЕРНЕТ-ТЕХНОЛОГІЙ У САМОСТІЙНІЙ РОБОТІ МАЙБУТНІХ ІНЖЕНЕРІВ У ПРОЦЕСІНАВЧАННЯ ІНОЗЕМНОЇ МОВИ
}

Герасимчук Т. В. Можливості інтернет-технологій у самостійній роботі майбутніх інженерів у процесі навчання іноземної мови.

у статті розглядаються проблеми застосування інтернет-технологій та організації самостійної діяльності майбутніх інженерів, що стимулює розкриття їхніх внутрішніх резервів, сприяє формуванню професійної іншомовної компетентності та позитивних соціальних і психологічних якостей особистості. Поняття інтерактивності розуміється як спосіб саморозвитку професійних якостей майбутніх фахівців інженерних спеціальностей за допомогою інформаційних технологій.

Ключові слова: інтернет-технології, інтерактивність, веб-сайт, самостійна діяльність майбутніх інженерів, формування професійної іншомовної компетентності, позитивні соціальні і психологічні якості особистості.

Герасимчук Т. В. Возможности интернет-технологий в самостоятельной работе будущих инженеров при обучении иностранному языку.

В статье рассматриваются проблемы использования интернет-технологий и организации самостоятельной деятельности будущих инженеров, что стимулирует раскрытие их внутренних резервов и способствует формированию профессиональной иноязычной компетентности и позитивных социальных и психологических качеств личности. Понятие интерактивности понимается как способ саморазвития профессиональных качеств будущих специалистов инженерных специальностей при помощи информационных технологий.

Ключевые слова: интернет-технологии, интерактивность, веб-сайт, самостоятельная деятельность будущих инженеров, формирование профессиональной иноязычной компетентности, позитивные социальные и психологические качества личности.

Gerasymchuk T. V. Possibilities of Internet technologies in self-guided work of future engineers in learning a foreign language.

This paper deals with the problems of the usage of Internet technology and organization of future engineers' self-guided work, which encourages disclosure of their internal reserves and promotes professional foreign language competence and positive social and psychological personality traits. The term of interactivity is understood as a way of selfmerit of competency of future engineers with the help of information technologies.

Key words: internet technology, interactivity, website, self-guided work of future engineers, the formation of professional foreign language competence, person's positive social and psychological characteristics.

Нині в умовах всесвітньої глобалізації розвиток інформаційних технологій сприяє утворенню нових способів використання Інтернету. У світі спостерігається послідовний i стійкий рух до побудови інформаційного суспільства, у якому формуються найкращі умови для максимальної самореалізації кожного фахівця. Підставами для такого процесу $\epsilon$ інтенсивний розвиток комп'ютерних i 
телекомунікаційних технологій та вдосконалення інформаційно-освітнього середовища.

Актуальною $є$ проблема впровадження інформаційно-комунікаційних технологій у процес навчання, розроблення особливих моделей і технологій, нових підходів до викладання іноземних мов, що мають на меті, по-перше, використання мови в реальному контексті, по-друге, необхідність розв'язання психолого-педагогічних завдань із використання комп'ютерних засобів у навчальному процесі на основі дотримання балансу між кращими методами традиційного навчання та інформаційними технологіями.

Проблему інформатизації вищої професійної освіти і психолого-педагогічного обгрунтування можливостей використання інформаційних технологій у вищій школі досліджували Б. Гершунський, Є. Машбиць, І. Роберт, В. Солдаткін та ін. Аналізу специфіки застосування інноваційних технологій навчання, зокрема інтернеттехнологій, а також створення навчальних веб-сайтів для самостійної роботи майбутніх інженерів у процесі навчання іноземної мови присвячено дослідження В. Беспалька, Н. Маслової, Н. Тализіної, Г. Селевка та ін.

Важливе значення для дослідження цих проблем $є$ обгрунтування аспектів компетентнісного, діяльнісного (Н. Баграмова, 3. Бакум, Н. Голуб, І. Дроздова, I. Зимня, Л. Мамчур, М. Пентилюк, Т. Симоненко, В. Шадриков та ін.) та особистісно зорієнтованого підходу (Ш. Амонашвілі, О. Бондаревська, О. Горошкіна, О. Копусь, В. Сєриков, І. Якиманська та ін.).

У науковій літературі знаходимо низку праць, присвячених питанням комп'ютерних та інформаційних технологій в освіті загалом і в навчанні іноземних мов зокрема (М. Акопова, Я. Ваграменко, Є. Полат, А. Хуторський та ін.); самостійної роботи студентів (Л. Жарова, І. Ільясов, Б. Ссипов, В. Ляудис, П. Підкасистий та ін.); проектної методики навчання (М. Вайсбург, О. Моїсєєва, Є. Полат, Д. Фрид-Бут, Т. Хатчинсон та ін.).

Оскільки зі стрімким наростанням обсягу інформації знання перестають бути самоціллю, вони постають умовою успішної реалізації особистості, іiі професійної діяльності. У цьому зв'язку важливо допомогти студентам стати активними учасниками процесу навчання і формувати в них потребу постійного пошуку. Відповідно постає завдання створення моделі навчального процесу, що дозволяла б розкривати й розвивати їхній творчий потенціал $[1 ; 2]$.

Meта статmi - проаналізувати проблеми застосування інтернет-технологій та організації самостійної діяльності майбутніх інженерів для формування їхньої професійної іншомовної компетентності та позитивних соціальних і психологічних якостей.

Нині лідером серед телекомунікаційних технологій стала всесвітня мережа Інтернет, оскільки різні засоби мультимедійних технологій розширюють можливості викладача, оптимізують вивчення мов, роблять його захоплюючим процесом відкриття незвіданого світу іноземної мови та культури.

Відрізняючись високим ступенем інтерактивності, інтернет-технології створюють унікальне навчально-пізнавальне середовище, яке можна використовувати для розв'язання різних дидактичних завдань із вивчення іноземної мови (наприклад, пізнавальних, інформаційних, культурних). Це $\epsilon$ однією 3 головних переваг комп'ютерної телекомунікації: вона замикає електронне інформаційне середовище, дозволяючи студентам і викладачам працювати з комп'ютером як 3 універсальним засобом оброблення інформації [2, с. 116-119; 3, с. 98-105]. 
Сучасні комп’ютерні телекомунікації можуть забезпечити передачу знань i доступ до різної навчальної інформації нарівні, а іноді й набагато ефективніше, ніж традиційні засоби навчання. Телекомунікації дозволяють здійснити принципово новий підхід до вивчення іноземних мов. Навчання з використанням інтернет-ресурсів $\epsilon$ сплавом нових інформаційних технологій із новими педагогічними: змінюється позиція викладача - він перестає бути «джерелом знань», а натомість виконує функції організатора i координатором процесу дослідження, пошуку, перероблення i збереження необхідної навчальної інформації, створення творчих робіт у здійсненні діяльнісного підходу до освіти.

Інтернет допомагає у формуванні вмінь і навичок розмовного мовлення, а також у навчанні лексики й граматики, забезпечуючи справжню зацікавленість та високу мотивацію діяльності й, отже, ефективність. Більше того,сприяє розвитку навичок, важливих не тільки для навчання іноземної мови, а й професійної мисленнєвої діяльності (розумові операції аналізу, синтезу, абстрагування, порівняння, зіставлення, вербального і смислового прогнозування та попередження тощо).

Інтернет розвиває соціальні та психологічні якості студентів- майбутніх фахівців різних галузей діяльності: їх упевненість у собі та здатність працювати в колективі; створює сприятливу для навчання атмосферу, постаючи засобом інтерактивного підходу до опанування професією.

Інтерактивність не просто створює реальні ситуації з ділового життя, а й змушує тих, хто навчається, адекватно реагувати на складні робочі ситуації за допомогою іноземної мови. Якщо отримано позитивний результат, можна говорити про досягнення професійної іншомовної компетентності, навіть за наявності мовних та мовленнєвих помилок. Головні вміння - спонтанно, гармонійно реагувати на висловлювання інших, виражаючи свої почуття та емоції, підлаштовуючись і перебудовуючись на ходу. Отже, ми розглядаємо інтерактивність як спосіб саморозвитку професійних якостей майбутніх фахівців інженерних спеціальностей через Інтернет: можливість спостерігати і копіювати кращі навички використання іноземної мови, зразки поведінки партнерів спілкування; розв'язувати нові проблеми під час їх спільного обговорення засобами іноземної мови.

Головним предметом вивчення іноземної мови $є$ розвиток усіх видів іншомовної діяльності і мислення, починаючи з усної комунікації і закінчуючи розвитком здібностей до різнопланової роботи з текстом задля одержання необхідної інформації. Навчання іноземної мови є багатогранним процесом, що насамперед підпорядкований основній меті - розвитку особистості студента, здатної брати участь у міжкультурній професійній комунікації іноземною мовою й самостійно вдосконалюватися в майбутній професії за допомогою іншомовної мовленнєвої діяльності [2]. Вища школа інженерного напряму готує своїх випускників безпосередньо до практичної діяльності з різних технічних спеціальностей, тому їх підготовка до використання знань з іноземної мови у зв'язку з майбутнім фахом набуває відповідної професійної спрямованості.

Освіта з залученням інтернет-технологій має безліч переваг щодо вивчення іноземної мови, зокрема англійської, що стає особливо актуальним у сучасному світі. Грамотне застосування нових видів самостійної роботи студентів та інтернеткомунікацій під час навчання іноземної мови дозволяе значно оптимізувати освітній процес і створювати автентичні ситуації професійного спілкування, що значно сприяє підвищенню рівня мотивації майбутніх інженерів під час вивчення іноземної мови.

Організація самостійної діяльності студентів із використанням Інтернету 
передбачає застосування новітніх педагогічних технологій, що стимулють розкриття внутрішніх резервів кожного студента, сприяючи формуванню професійної компетентності фахівця та соціальних і психологічних якостей особистості (самовпевненість і здатність працювати в колективі, виконуючи різні соціальні ролі, допомагаючи один одному в спільній діяльності, ухвалюючи спільними зусиллями складні пізнавальні завдання). Крім того, система Інтернет надає широкі можливості для організації різних навчальних проектів. Виокремлюють два види проектів: WWWпроекти, E-mail-проекти. WWW-проекти розраховані на те, що студенти отримують завдання, для виконання яких їм необхідно знайти інформацію в Інтернеті та представити потім результати свого пошуку.

Під час формування самостійної навчальної діяльності за допомогою Інтернету необхідно, щоб мовний матеріал був емоційно забарвлений, мав цілеспрямоване значення, ураховувалися професійні інтереси учнів. Задля досягнення емоційної забарвленості навчання іноземної мови необхідно використовувати Інтернет для поєднання різних видів навчальної діяльності, включення в навчальний процес комунікативної діяльності, використання пізнавальних та автентичних текстів [3]. У процесі роботи в Інтернеті студенти ознайомлюються 3 країнознавчої інформацією, культурними аспектами країни виучуваної мови, персональними сайтами відомих фахівців.

Сучасні педагогічні технології, такі, як навчання у співпраці, проектна методика використання нових інформаційних технологій, інтернет-ресурсів допомагають реалізувати особистісно орієнтований підхід у навчанні, забезпечують індивідуалізацію і диференціацію навчання з урахуванням здібностей учнів, їхнього рівня навченості, схильностей тощо.

Розглянемо модель організації самостійної роботи студентів технічних ВНЗ на основі використання персонального веб-сайту викладача як централізованого засобу інтеграції інтернет-технологій у процес іншомовної підготовки фахівця.

Навчальний веб-сайт є поширеним засобом подання навчальної інформації в Інтернеті [6, с. 96], проте це поняття (website) ще потребує окремого детального розгляду. Т. Яшина розуміє під навчальним веб-сайтом сукупність веб-сторінок 3 єдиним дизайном, за допомогою яких здійснюється цілеспрямований процес навчання; веб-сторінки об'єднані за змістом, навігаційно та фізично розміщені на одному сервері. Використання навчального веб-сайту може супроводжуватися атестацією студентів [9, с. 168]. І. Государев визначає навчальний веб-сайт як інформаційний ресурс навчального призначення, виконаний засобами вебтехнологій [4, с. 278].

Така модель може бути використана для організації самостійної роботи студентів різних спеціальностей, що дозволяє реалізувати:

1) інтеграцію можливостей мережі Інтернет в процес професійної іншомовної підготовки майбутніх інженерів, сприяє підвищенню якості навчального процесу, оптимізації та інтенсифікації процесу навчання іноземної мови, а також формуванню іншомовної професійної комунікативної компетентності студентів ВТНЗ;

2) ефективну інтеграцію можливостей мережі Інтернет, що досягається використанням викладачем іноземної мови персонального веб-сайту в якості централізованого впровадження інтернет-технологій задля організації самостійної роботи студентів та підтримки навчального процесу;

3) самостійну роботу студентів за допомогою їх участі в спеціально розроблених видах діяльності іноземною мовою: самостійна робота $з$ електронними ресурсами та 
інтернет-комунікація. Персональний веб-сайт викладача іноземної мови, використовуючи інформаційні та комунікативні служби мережі Інтернет, дозволяє ефективно організувати самостійну роботу студентів й керувати нею, а також надає студентам інформацію різного виду, що підвищує доступність та якість освіти;

4) структура і сервіси веб-сайту дозволяють адаптувати його інформаційне наповнення до цілей і завдань навчального процесу у вищій школі, ураховувати індивідуальні особливості та специфічні потреби як студентів, так і викладача, забезпечити також постійний зворотний зв'язок між ними.

Веб-сайт викладача іноземної мови - окремий вид освітнього веб-сайту, а саме: особливим способом оформлена й організована сукупність веб-сторінок, об'єднана одним дизайном задля організації самостійної роботи студентів і підтримки викладачем процесу навчання іноземної мови для формування іншомовної професійної комунікативної компетентності студентів. Метою веб-сайту викладача іноземної мови є не тільки надання інформації з іноземної мови для використання студентами в процесі навчання, а й організація навчального процесу, стимуляція пізнавальної діяльності та підвищення мотивації, і нарешті, формування професійної компетентності іноземною мовою. При цьому веб-сайт дозволяє централізувати використання основних можливостей мережі Інтернет. Під час роботи над створенням персонального веб-сайту викладача визначено такі етапи:

- визначення цілей і завдань веб-сайту;

- аналіз сучасних освітніх веб-сайтів викладачів;

- визначення обмежень і реакцій на використання різних технологій;

- підготовка змісту веб-сайту і його фізичне проектування;

- безпосереднє створення структури веб-сайту та іiі подальше змістове наповнення;

- проведення тестування на швидкість завантаження;

- легкість використання, правильну роботу покликань, стилістичну та орфографічну коректність;

- розміщення веб-сайту в Інтернеті та інформування цільової аудиторії про його доступність;

- своєчасна підтримка веб-сайту;

- коректування структури та змісту в міру необхідності.

Навчання в поєднанні 3 інтернет-технологіями на основі персонального вебсайту викладача сприятиме оптимізації навчального процесу та підвищенню ефективності самостійної роботи студентів за рахунок реалізації таких основоположних принципів рейтингової системи, як принципи відкритості, доступності та гласності.

Для оцінки ефективності застосування веб-сайту викладача як централізованого засобу інтеграції інтернет-технологій у процес навчання іноземної мови використовуються такі показники [7; 8, с. 151-153]:

- дані, що відображають відвідуваність сайту студентами;

- кількість отриманих листів і їх контент-аналіз;

- результати анкетування студентів.

У процесі оцінювання ефективності організації самостійної діяльності при інтеграції інтернет-технологій на основі персонального веб-сайту викладача враховуються такі показники:

- зміна рівня мотивації;

- оцінка обсягу та якості виконаної самостійної роботи студентів; 
- дані анкетування студентів, що дозволяють 3'ясувати їх ставлення до використання інтернет-технологій у процесі навчання іноземної мови.

Подана модель навчання майбутніх інженерів задля формування їхньої професійної іншомовної компетентності має бути побудована на основі компетентнісного, діяльнісного та особистісно зорієнтованого підходів з урахуванням дидактичних принципів навчання.

Використання нових інформаційних технологій у навчанні іноземних мов має чималий педагогічний потенціал, будучи одним із засобів, що перетворюють навчання іноземної мови в живий творчий процес. Звичайно, комп'ютер - це лише складна машина на службі у людини, і вона ніколи не замінить викладача. Однак, як говорив Білл Гейтс: «Усі комп’ютери в світі нічого не змінять без наявності захоплених учнів, ерудованих і відданих своїй справі викладачів». Акцент слід зробити на самостійній роботі студентів з електронними ресурсами мережі Інтернет іноземною мовою в спеціально розроблених видах діяльності, а також на інтернеткомунікації, що сприятиме формуванню іншомовної професійної комунікативної компетентності.

Інтернет-ресурси надають майбутнім інженерам змогу творчо застосовувати опрацьований мовний матеріал на базі своїх професійних знань i дозволяють адаптуватися до реальних і потенційно можливих виробничих ситуацій. Будучи інтерактивним методом навчання, він завойовує позитивне ставлення студентів, які вбачають змогу виявлення ініціативи, відчуття самостійності в опануванні теоретичних положень та оволодінні практичними знаннями і навичками.

\section{Література}

1. Андреев А. А. Введение в Интернет-образование: [учеб. пособие]/ А. А. Андреев. - М. : Логос, 2003. - 76 с. 2. Ажель Ю. П. Особенности внедрения Интернет-технологий в организацию самостоятельной работы студентов при обучении иностранным языкам в неязыковом вузе / Ю. П. Ажель // Молодой ученый. - 2011. - № 6. - Т. 2. - С. 116-119. 3. Беркимбаев К. М. Использование Интернет-ресурсов при обучении иностранным языкам в вузе / К. М. Беркимбаев, Б. К. Мухамеджанов, С. Т. Нышанова, Б. Т. Керимбаева // Вестник Российского университета дружбы народов. - Серия информатизации. - 2012. - № 2. - С. 98-105. 4. Государев И. Б. Проблемы профильногообучениявеб-технологиям в старшейшколе / И. Б. Государев // Х Санкт-Петербургская Междунар. конф. «Региональнаяинформатика - 2004».- СПб., 2004. - С. 278. 5. Жук Л. Г. Внедрение интернет-технологий обучения в профессиональное образование / Л. Г. Жук // Научно-технические ведомости СПбГТУ. - СПб. - 2006. - № 4 (46). - С. 121-123. 6. Матвєєва С. А. Сайт як жанр Інтернет-комунікацій (на матеріалі персональних сайтів учених) : дис. ...канд. філол. наук : 10.02.15 / С. А. Матвєєва. - Луганськ, 2006. - 212 с. 7. Панина Г. С. Современные способы активизации обучения :[учеб. пособ. для студ. высш. учеб. заведений]/ Т. С. Панина, Л. Н. Вавилова; под ред. Т. С. Паниной. - М. : ИЦ «Академия», 2006. - 176 с. 8. Строева А. А. Контент-анализ статей, посвященных использованию Интернета в преподавании иностранного язика / А. А. Строева, Л. Г. Жук// XXXIII Неделя науки СПбГПУ: материалы Всерос. межвуз. науч-технич. конфер. студ. и аспир. - СПб. : СПбГПУ, 2005. - Ч. VIII. С. 151-153. 9. Яшина Т. С. Оценкакачества образовательных веб-сайтов как фактор развитияединого информационногообразовательногопространства : дис. ... канд. пед. наук : 13.00.01 / Т. С. Яшина. - Воронеж, 2005. - 205 с. 